\title{
EFFICACY OF ROBOT-ASSISTED PHYSIOTHERAPY FOR PAIN MANAGEMENT IN NEUROLOGICAL DISORDERS: A SYSTEMATIC REVIEW
}

\author{
Okasha Anjum, Hajra Ameer Shaikh, Nida Waheed, Syeda Wajeeha Raza Zaidi \\ Department of Physical Therapy and Rehabilitation Sciences, Indus University, Karachi - Pakistan
}

\begin{abstract}
Objective: Neurological disorders (ND) are ranked as the leading cause of death and disability around the globe and the escalating burden summons the advancements in the treatment strategies hence this systematic review aimed to fill the knowledge gap regarding the efficacy of robot-assisted physiotherapy (RAPT) for pain management in ND.

Materials and method: Scientific trials were sought by an extensive search via electronic databases mainly PubMed, PEDro and Scopus. Randomized controlled trials published from the year 2014 to April 2021, evaluating the potential effects of RAPT for pain management in ND were included in the review. The quality appraisal of the RCTs was analyzed via Cochrane tool for assessing risk of bias.

Results: The majority of the trials reported the effectiveness of RAPT using PARO robot, Armeo spring, Gloreha robot, and robotic Lokomat gait training system in significantly improving pain of ND such as stroke, dementia, phantom syndrome, and spinal cord injuries.
\end{abstract}

Conclusion: Large body of evidence suggested RAPT as a potential solution in improving pain of various ND. However, further rigorous trials are necessary to draw conclusive recommendations.

Keywords: Neurological disorders, pain, physiotherapy management, rehabilitation, robot-assisted physiotherapy, robotics

This article may be cited as: Anjum O, Shaikh HA, Waheed N, Zaidi SWR. Efficacy of robot-assisted physiotherapy for pain management in neurological disorders: a systematic review. J Med Sci 2021 July;29(3):126-131

\section{INTRODUCTION}

Neurological disorders (ND) are ranked as the second leading cause of death around the globe ${ }^{1}$. Among these disorders, stroke is the number one cause ${ }^{2}$. ND accounts for $6.3 \%$ of the global burden of diseases ${ }^{3}$. Furthermore, it is expected to raise, hence demands advancements in the treatment strategies.

Robotics is one of the most emerging gap areas in the neuro-rehabilitation panorama. Growing evidence claimed robot-assisted physiotherapy (RAPT) as a promising approach to provide feasible ${ }^{4}$, accurate, repeatable, quantifiable, patient-centered therapy, while guaranteeing patient safety, speedy recovery, and unloading therapist workload as compared to traditional methods and also helps to maximize and maintain the therapy dose $\mathrm{s}^{5,6,7}$.

According to World Health Organization (WHO),

\section{Correspondence}

Dr. Hajra Ameer Shaikh (PT)

Lecturer, Department of Physical Therapy and Rehabilitation Sciences, Indus University, Karachi - Pakistan

Email: hajraameer90@gmail.com

Cell: +92-342-2332987

Date received: $02-02-2021$

Date revised: $02-07-2021$

Date accepted: 03-08-2021
ND are progressive and challenging health problem ${ }^{8}$. Scientific pieces of literatures reported pain as the common complaint of patients suffering from $\mathrm{ND}^{9}$, greatly impacting the Quality Of Life (QOL) ${ }^{10}$, also reduces patient adherence and treatment satisfaction ${ }^{11}$. Hence making the management of pain difficult ${ }^{12}$. Recently a multicenter experimental trial conducted by Aprile et al. concluded Robotic Therapy (RT) to be effective in reducing pain in stroke patients ${ }^{13}$. Well-documented researches show that robotic therapy utilizes various games that not only makes it interesting for the patients with ND but also allows them to be more independent, improve pain, QOL and promotes adherence to rehab program ${ }^{14,15}$. Ample researches also claimed RT to be more effective than conventional therapy furthermore it is also reported to be cost effective ${ }^{16,17}$ and in improving cognitive function ${ }^{18}$.

Previous systematic review and meta-analysis have reported RT to be effective in improving Activities of Daily Living (ADLs), motor control, and muscle strength of stroke survivors also identifies knowledge gaps in robotic rehabilitation ${ }^{19-21}$.

It is noteworthy that despite the incredible effects of RAPT elucidated in the literature however in the field of neuro-rehabilitation the evidence regarding the efficacy of robotics for pain management in ND is still in infancy. 
Efficacy Of Robot-Assisted Physiotherapy For Pain Management In Neurological Disorders: A Systematic Review

Therefore, this systematic review (SR) is aimed to evaluate the efficacy of RAPT for pain management in ND.

\section{MATERIAL \& METHODS}

Study Design: A SR was carried-out on Randomized Controlled Trials (RCTs) conducted on patients suffering from ND including stroke, dementia, spinal cord injury (SCl), and phantom- limb syndrome.

Review Protocol: The protocol for this SR is reported in consideration with the PRISMA (Preferred Reporting Items for Systematic Reviews and Meta-Analyses) recommendations ${ }^{22}$.

Eligibility Criteria: Trials that met the following eligibility criteria were included:

1. Study design must be RCT.

2. Patients diagnosed with any type of ND, aged $\geq 18$ years.

3. Studies addressing neuropathic pain as the main outcome measure.

4. RCTs published from 2014 to April 2021.

5. RCTs available in the English language.

Sources of information: Numerous electronic databases including PubMed, Scopus, PEDro, Web of Science, Cochrane Library, Scopus, and Med-line were scanned.

Search strategy: In January 2021, a systematic search was executed using various electronic databases in order to find out potentially eligible published trials. The key terms include ("Robotic therapy" OR "Robot-assisted physiotherapy ") AND ("neuropathic pain" OR "pain") AND ("neurological disorders" OR " stroke" OR "spinal cord injury" OR "dementia" OR "phantom limb syndrome" OR "Parkinson") AND ("physiotherapy" OR "physical activity" OR" exercise" OR " neurological rehabilitation") AND ("RCT" OR " randomized controlled trial") AND " custom date range (2014 to 2021)". Moreover additional trials were extracted using the reference list of the included RCTs. Initially the titles and/or abstracts were assessed for eligibility and trials not meeting the criteria for eligibility were excluded. However, the eligible trials were rigorously reviewed in full to appraise the credibility in consideration with the PRISMA recommendations.

Trials Selection: Initial filtration of articles was done based on the titles and/or abstracts also investigated against the inclusion criteria of the SR. Total 132 trials were pooled-out by the primary search. Out of these, some trials were irrelevant, others full-text were not accessible, replicated or having the poor methodological quality or not available in the English language. However eight potential trials addressing the efficacy of RAPT for pain management in different ND were included in this SR. The disagreements regarding the trials were resolved after a combined discussion of all the authors.

Extraction of Data: The data such as principle author name, trial publication year, the population of the study, sample size, treatment applied, and the main findings of the trial were extracted from the selected trials.

Risk of Bias: Critical appraisal of the trials was carried-out for evaluating the methodological quality by using the Cochrane tool for assessing risk of bias ${ }^{23}$. This tool assesses the biases in various domains which includes random allocation, allocation concealment, blinding of participants and outcome assessment, incomplete outcome data, selective reporting and other bias.

\section{RESULTS}

Selection of studies: A total 132 trials were retrieved after the initial systematic search through different databases. However 115 articles were excluded based on titles, objectives and replication, remaining 17 full-text RCTs were reviewed, of which eight potential trials ${ }^{24-31}$ were included in this SR. The selection strategy of the trials is shown in the PRISMA flow diagram (Figure 1).

Characteristics of Studies: Total RCTs included in this review involve 242 neurological patients suffering from stroke, dementia, phantom upper limb syndrome, and SCl. The included trials were conducted from December 2014 to September 2020. Few trials reported sample size calculation. The total follow-up periods of the studies ranges from three weeks to one and half months. Different outcomes measures were used i.e. NPRS, VAS, NRPS, and PAINAD ${ }^{24-31}$ (Table 1).

Abbreviations: Exercises (Ex's), Joint Mobilization Technique (JMT), Passive Range Of Motion (PROM), Random Training (RT), Conventional Physiotherapy (CPT), Upper Extremity (UE), Experimental Group (EG), Control Group (CG), Robotic Therapy (RT), Spinal Cord Injury (SCl), Strength Training (ST), Robotic Assisted Gait Training (RGAT), Adduction (Add), Abduction (Abd), Flexion (Flex) and Extension (Ext).

Results of the studies related to the evaluation of pain in neurological patients: Pu Lihui et al. conducted various trials ${ }^{24,25,27}$ on dementia patients using PARO robot and reported a significant decrease in pain in all studies. Another research conducted by Taveggia $G$ et al. ${ }^{30}$ in Italy compared Armeo spring robotic device versus traditional physiotherapy results revealed more improvement in pain in patients receiving Armeo spring robotic therapy. Similarly, the pain had also decreased significantly in poststroke hemiplegic shoulder patients receiving Gloreha RT along with passive ROM and stretching ex's ${ }^{29}$. The majority of the trials reported improvement in pain in different ND using RAPT ${ }^{24-31}$. No study documented any side effects of the use of robot. 
Efficacy Of Robot-Assisted Physiotherapy For Pain Management In Neurological Disorders: A Systematic Review

Table 2. Cochrane summary of the risk of bias Indications: High risk of bias (-), low risk of bias $(+)$ and unclear risk of bias (?), Higgins et al. ${ }^{23}$.

Risk of bias within trials and quality appraisal: All the selected trials had a low risk of bias in random allocation ${ }^{24-31}$. Six of the trials showed a high risk of biasness in allocation concealment, ${ }^{24-28,31}$ however only one trial showed a low risk of bias ${ }^{29}$. The majority of the studies didn't show participant blinding ${ }^{24-27,31}$ but the studies by Kim MS et al. ${ }^{28}$, Villafane et al. ${ }^{29}$ and Taveggia et al. ${ }^{30}$ reported participant blinding. All the trials showed a low risk of bias in selective reporting, except Kim et al. ${ }^{28}$. The risk of bias could not be determined because of the poor methodological quality of a few studies ${ }^{30-31}$ (Table 2).

Table 1: Synopsis of the trials related to the efficacy of RAPT for pain management in ND

\begin{tabular}{|c|c|c|c|c|c|c|c|c|}
\hline Authors & $\begin{array}{c}\text { Pu Lihui et } \\
\text { al. } 24\end{array}$ & $\begin{array}{c}\text { Pu Lihui et } \\
\text { al.25 }\end{array}$ & $\begin{array}{c}\text { Yanagi et } \\
\text { al.26 }\end{array}$ & $\begin{array}{c}\text { Pu Lihui et } \\
\text { al.27 }\end{array}$ & Kim et al.28 & $\begin{array}{c}\text { Villafane et } \\
\text { al.29 }\end{array}$ & $\begin{array}{c}\text { Taveggia et } \\
\text { al.30 }\end{array}$ & $\begin{array}{c}\text { Labruyère } \\
\text { et al. } 31\end{array}$ \\
\hline Year & 2020 & 2020 & 2020 & 2019 & 2019 & 2018 & 2016 & 2014 \\
\hline $\begin{array}{c}\text { Study } \\
\text { Population }\end{array}$ & Dementia & Dementia & $\begin{array}{l}\text { Phantom } \\
\text { syndrome }\end{array}$ & Dementia & Stroke & Stroke & Stroke & $\begin{array}{l}\text { Incomplete } \\
\text { SCl }\end{array}$ \\
\hline Sample size & $n=43$ & $n=43$ & $n=12$ & $n=11$ & $n=38$ & $n=32$ & $n=54$ & $n=9$ \\
\hline Intervention & $\begin{array}{c}E G=\text { Re- } \\
\text { ceived PARO } \\
\text { RT (A baby } \\
\text { harp robot } \\
\text { that rehabili- } \\
\text { tates using its } \\
\text { four senses } \\
\text { sight, hearing, } \\
\text { balance, } \\
\text { tactile sense } \\
\text { and talk with } \\
\text { user also } \\
\text { CG = Usual } \\
\text { care activity } \\
\text { (singing, story } \\
\text { and music } \\
\text { listening) } \\
30 \text { mins ses- } \\
\text { sion, } 5 \text { days/ } \\
\text { wk. Total } 30 \\
\text { sessions }\end{array}$ & $\begin{array}{c}\mathrm{EG}=\text { PARO } \\
\text { RT } \\
\text { CG= Usual } \\
\text { care activity } \\
\text { (singing, } \\
\text { story and } \\
\text { music listen- } \\
\text { ing) } \\
30 \text { mins ses- } \\
\text { sion, } 5 \text { days/ } \\
\text { wk. Total } 30 \\
\text { sessions }\end{array}$ & $\begin{array}{c}E G=A s- \\
\text { signed real } \\
\text { training. } \\
\text { CG=As- } \\
\text { signed RT } \\
\text { MEG signals } \\
\text { were record- } \\
\text { ed when } \\
\text { different } \\
\text { phantom } \\
\text { hand move- } \\
\text { ments were } \\
\text { performed. } \\
\text { Real training } \\
\text { includes } 400 \\
\text { ms virtual } \\
\text { training and } \\
\text { in RT } 200 \\
\text { ms virtual } \\
\text { images were } \\
\text { controlled. } \\
\text { Total } 28 \\
\text { sessions }\end{array}$ & $\begin{array}{c}E G=\text { PARO } \\
\text { RT } \\
\text { CG = Usual } \\
\text { care } \\
30 \text { mins ses- } \\
\text { sion, } 5 \text { days/ } \\
\text { wk. Total } \\
30 \text { sessions }\end{array}$ & $\begin{array}{c}\text { Bobath } \\
\text { approach } \\
\text { and physical } \\
\text { modalities } \\
\text { were given } \\
\text { to both the } \\
\text { gps. } \\
\text { EG= Ro- } \\
\text { bot-assisted } \\
\text { shoulder } \\
\text { JMT and } \\
\text { stretching } \\
\text { ex's } \\
\text { CG= PROM } \\
\text { ex's } \\
30 \text { mins ses- } \\
\text { sion, } 5 \text { days/ } \\
\text { wk. Total } 20 \\
\text { sessions }\end{array}$ & $\begin{array}{l}\text { Both groups } \\
\text { received } \\
\text { CPT includ- } \\
\text { ing assisted } \\
\text { stretching, } \\
\text { shoulder } \\
\text { and arm } \\
\text { ex's and } \\
\text { functional } \\
\text { reaching } \\
\text { task. } \\
\text { EG= } \\
\text { Received } \\
\text { additional } \\
\text { passive } \\
\text { mobilization } \\
\text { of hand } \\
\text { through } \\
\text { Gloreha } \\
30 \text { mins ses- } \\
\text { sion, } 3 \text { days/ } \\
\text { wk. Total } 9 \\
\text { sessions }\end{array}$ & $\begin{array}{c}\text { EG= Armeo } \\
\text { spring } \\
\text { robotic UE } \\
\text { movement } \\
\text { + postural } \\
\text { correction } \\
\text { + CPT (ac- } \\
\text { tive-assisted } \\
\text { and passive } \\
\text { mobilization } \\
\text { of UE based } \\
\text { on bobath } \\
\text { concept). } \\
5 x d / \text { wk. } \\
\text { CG = CPT } \\
30 \text { mins ses- } \\
\text { sion } 5 \text { days/ } \\
\text { wk. Total } 30 \\
\text { sessions }\end{array}$ & $\begin{array}{c}\text { EG=R- } \\
\text { GAT-ST } \\
\text { CG=ST- } \\
\text { RGAT } \\
\text { RGAT is } \\
\text { controlled } \\
\text { via Lokomat } \\
\text { system in } \\
\text { which virtual } \\
\text { gait training } \\
\text { was done. } \\
\text { ST including } \\
\text { isotonic } \\
\text { leg press } \\
\text { in supine } \\
\text { position and } \\
\text { isotonic hip } \\
\text { add, abd, } \\
\text { flex and ext. } \\
45 \text { mins ses- } \\
\text { sion, } 4 \text { days/ } \\
\text { wk. Total } 16 \\
\text { sessions }\end{array}$ \\
\hline Main finding & $\begin{array}{c}\text { PARO RT re- } \\
\text { duces chronic } \\
\text { pain }\end{array}$ & $\begin{array}{c}\text { Significant } \\
\downarrow \text { in pain } \\
\text { observes } \\
\text { in EG as } \\
\text { compared } \\
\text { to CG }\end{array}$ & $\begin{array}{l}\text { Pain sig- } \\
\text { nificantly } \\
\text { reduced via } \\
\text { real training }\end{array}$ & $\begin{array}{l}\text { EG reported } \\
\text { significant } \downarrow \\
\text { in pain }\end{array}$ & $\begin{array}{c}\text { EG had } \\
\text { shown } \\
\text { significant } \downarrow \\
\text { in pain }\end{array}$ & $\begin{array}{l}\text { RT is more } \\
\text { effective } \\
\text { in treating } \\
\text { post stroke } \\
\text { shoulder } \\
\text { pain }\end{array}$ & $\begin{array}{c}\text { Both gps } \\
\text { reported } \\
\text { significant } \\
\downarrow \text { in pain } \\
\text { however, EG } \\
\text { shows more } \\
\text { improve- } \\
\text { ment }\end{array}$ & $\begin{array}{l}\text { Pain } \downarrow \text { in } \\
\text { both groups }\end{array}$ \\
\hline
\end{tabular}

Table 2: Table 2. Cochrane summary of the risk of bias

\begin{tabular}{|c|c|c|c|c|c|c|c|}
\hline $\begin{array}{c}\text { Randomised } \\
\text { Controlled Trial }\end{array}$ & $\begin{array}{c}\text { Random } \\
\text { Allocation }\end{array}$ & $\begin{array}{c}\text { Allocation } \\
\text { Concealment }\end{array}$ & $\begin{array}{c}\text { Participants } \\
\text { Blinding }\end{array}$ & $\begin{array}{c}\text { Outcome } \\
\text { Assessment } \\
\text { Blinding }\end{array}$ & $\begin{array}{c}\text { Incomplete } \\
\text { Outcome } \\
\text { Data }\end{array}$ & $\begin{array}{c}\text { Selective } \\
\text { Reporting }\end{array}$ & $\begin{array}{c}\text { Other Bias } \\
\text { Pu Lihui et al.24 }\end{array}$ \\
\hline Pu Lihui et al.25 & + & - & - & - & + & + & + \\
\hline Yanagisawa et al.26 & + & - & - & - & + & + & + \\
\hline Pu Lihui et al.27 & + & - & - & + & + & + & + \\
\hline Kim et al.28 & + & - & - & - & + & - & + \\
\hline Villafane et al.29 & + & - & + & + & + & + & + \\
\hline Taveggia et al.30 & + & + & + & + & + & + & + \\
\hline Labruyere et al. 31 & + & - & - & + & + & + \\
\hline
\end{tabular}


Efficacy Of Robot-Assisted Physiotherapy For Pain Management In Neurological Disorders: A Systematic Review

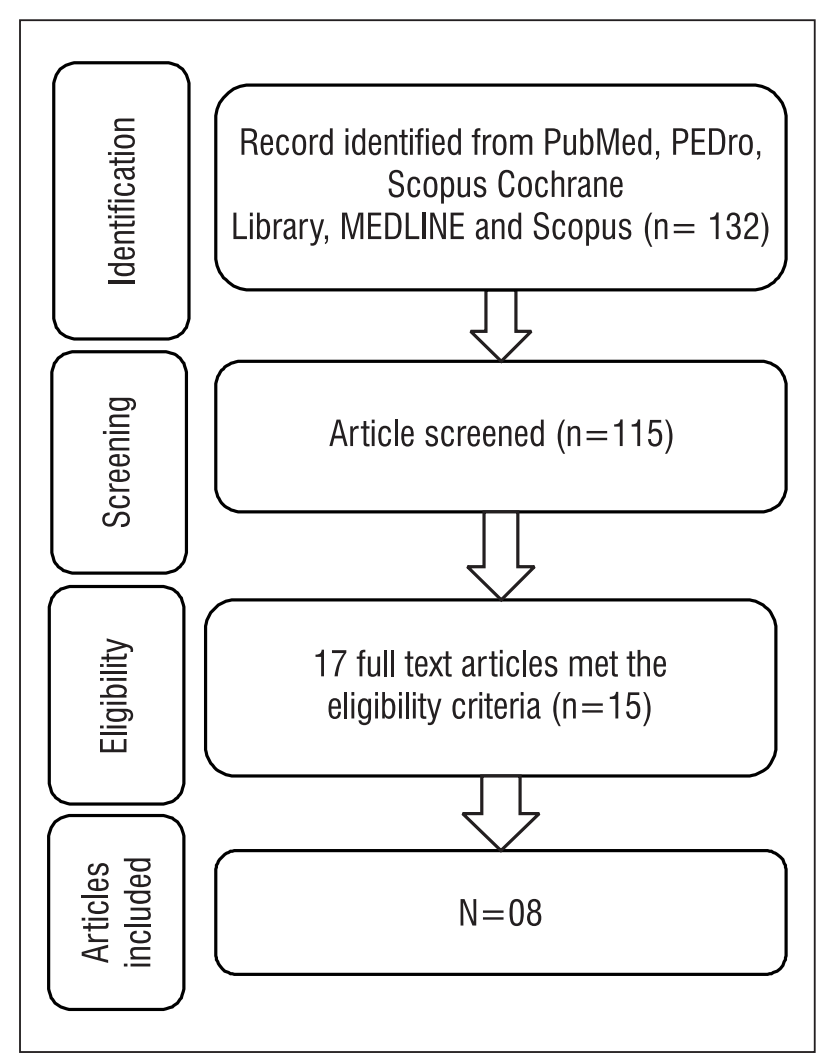

Figure 1. Trials selection strategy

Synthesis of results: The majority of the trials reported the effectiveness of RAPT using PARO robot, Armeo spring, Gloreha robot and robotic Lokomat gait training system in significantly improving the pain of various ND such as stroke, dementia, phantom syndrome and $\mathrm{SCl}$.

\section{DISCUSSION}

This comprehensive review is the first to address the knowledge gap regarding the efficacy of RAPT for pain management in ND by rigorously scanning the latest RCTs conducted over the past 8 years. This SR examines eight quality trials including, 242 neurological patients suffering from stroke, dementia, phantom upper limb syndrome, and incomplete $\mathrm{SCl}$.

A fascinating study by Villafane $\mathrm{JH}$ et al. ${ }^{29}$ reported RAPT to be more effective than Conventional Physiotherapy (CPT) alone. However, these findings are contradicted by a recent (2021) case-control study conducted in Italy by Paolucci et al. ${ }^{32}$, which suggested that robot-assisted rehabilitation and CPT both are equally effective in reducing pain in chronic stroke patients. Similarly, another study by Abdullah et al. also reported no significant difference ${ }^{33}$.

The current SR mainly highlights the role of robotics for pain management. However a previous, meta-analysis published by Rachele Bertani et al. ${ }^{34}$ documented RT effectiveness in the recovery of upper limb motor function specifically in stroke patients. The same findings were observed by Fernanda et al. ${ }^{35}$ with emphasis that RT is not only effective in motor function improvement but also in enhancing the strength of muscles in the same population. Nirit Geva et al. ${ }^{36}$ added that RT is also effective in improving the moods of patients. However, these researches claimed the lack of quality data availability.

It is noteworthy that the findings of this review are in line with the studies conducted by Ach et al. ${ }^{37}$, Cruciger et al. ${ }^{38}$ and Stampacchia et al. ${ }^{39}$ which further endorsed the imperative role of RT in the reduction of neurological pain. However, Remi et al. ${ }^{40}$ claimed no significant pain reduction in stroke patients after RT.

This review is the first to elucidate an up-to-date finding regarding the emerging role of RAPT in neurological pain management and addresses major health implications however some potential limitations associated with this review include few numbers of trials with a small sample size. Furthermore, a variety of robotic therapies were categorized under the term RAPT.

As the blooming role of robotics in neurological rehabilitation still lies in its infancy, therefore a robust and reliable conclusion cannot be drawn. Hence, it is recommended that further quality trials with large sample size and long follow up duration addressing dose-response of different robotic therapies and patients independent handling is the need of time to explore precise effects of this innovative treatment strategy.

\section{CONCLUSION}

A large body of evidence supports the effectiveness of RAPT for improving pain in various ND such as stroke, dementia, phantom syndrome, and SCl. However due to scarcity of the evidence on robotic rehabilitation, a reliable and robust conclusion cannot be drawn. Further high quality, rigorous, multi-center, and large-scale trials are necessary to draw conclusive recommendations.

\section{ACKNOWLEDGEMENT}

We would like to acknowledge Dr. Yumna Ali, a PhD scholar from Italy for critically reviewing this SR and giving us valuable feedback and suggestions.

All the authors are agreed to be accountable for the authenticity and integrity of this SR.

\section{REFERENCES}

1. Feigin VL, Nichols E, Alam T, et al. Global, regional, and national burden of neurological disorders, 1990-2016: a systematic analysis for the Global Burden of Disease Study 2016. Lancet Neurol 2019; 18: 459-80.

2. Jenkins C, Arulogun OS, Singh A, et al; SIREN Team. Stroke Investigative Research and Education Network: Community Engagement and Outreach within Phenomics Core. Health Educ Behav. 2016; 43:82S-92S. 
3. Dua T, Cumbrera MG, Mathers C, et al. Global burden of neurological disorders: estimates and projections. In: Neurological disorders: public health challenges. Geneva, Switzerland: World Health Organization, 2006: 27-39.

4. Colombo R, Sanguineti V. Rehabilitation Robotics: Technology and Applications. London: Elsevier Academic Press; 2018.

5. Daly JJ, McCabe JP, Holcomb J, Monkiewicz M, Gansen $\mathrm{J}$, Pundik S. Long-dose intensive therapy is necessary for strong, clinically significant, upper limb functional gains and retained gains in severe/moderate chronic stroke. Neurorehabilitation and neural repair. 2019 Jul;33(7):523-37.

6. Zollo L, Gallotta E, Guglielmelli E, Sterzi S. Robotic technologies and rehabilitation: new tools for upper-limb therapy and assessment in chronic stroke. European journal of physical and rehabilitation medicine. 2011 Mar 29;47(2):223-36.

7. Ward NS, Brander F, Kelly K. Intensive upper limb neurorehabilitation in chronic stroke: outcomes from the Queen Square programme. Journal of Neurology, Neurosurgery \& Psychiatry. 2019 May 1;90(5):498-506.

8. Janca A, Aarli JA, Prilipko L, Dua T, Saxena S, Saraceno B. WHO/WFN Survey of neurological services: a worldwide perspective. Journal of the neurological sciences. 2006 Aug 15;247(1):29-34.

9. Borsook D. Neurological diseases and pain. Brain. 2012 Feb 1;135(2):320-44.

10. Bates D, Schultheis BC, Hanes MC, Jolly SM, Chakravarthy KV, Deer TR, Levy RM, Hunter CW. A comprehensive algorithm for management of neuropathic pain. Pain Medicine. 2019 Jun 1;20(Supplement_1):S2-12.

11. Zilliox LA. Neuropathic pain. CONTINUUM: Lifelong Learning in Neurology. 2017 Apr 1;23(2):512-32.

12. Deng Y, Luo L, Hu Y, Fang K, Liu J. Clinical practice guidelines for the management of neuropathic pain: a systematic review. BMC anesthesiology. 2015 Dec;16(1):1-0.

13. Aprile I, Germanotta M, Cruciani A, Pecchioli C, Loreti S, Papadopoulou D, Montesano A, Galeri S, Diverio M, Falsini C, Speranza G. Poststroke shoulder pain in subacute patients and its correlation with upper limb recovery after robotic or conventional treatment: A secondary analysis of a multicenter randomized controlled trial. International Journal of Stroke. 2020 Jul 8.

14. Prange GB, Kottink Al, Buurke JH, Eckhardt MM, van Keulen-Rouweler BJ, Ribbers GM, Rietman JS. The effect of arm support combined with rehabilitation games on upper-extremity function in subacute stroke: a randomized controlled trial. Neurorehabilitation and neural repair. 2015 Feb;29(2):174-82.

15. H. I. Krebs and N. Hogan, "Robotic therapy," American Journal of Physical Medicine \& Rehabilitation, 2012 vol. 91, no. 11 Suppl : 290-S297.

16. Cho K, Yu J, Jung J. Effects of Virtual Reality-Based Rehabilitation on Upper Extremity Function and Visual Perception in Stroke Patients: a Randomized Control Trial. J Phys Ther Sci 2012;24:1205-8.

17. Coupar FM. Exploring upper limb interventions after stroke. University of Glasgow; 2012.
18. Aprile I, Guardati G, Cipollini V, Papadopoulou D, Mastrorosa A, Castelli L, Monteleone S, Redolfi A, Galeri S, Germanotta M. Robotic rehabilitation: an opportunity to improve cognitive functions in subjects with stroke. An explorative study. Frontiers in Neurology. 2020 Nov 19;11:1498.

19. Mehrholz J, Pohl M, Platz T, Kugler J, Elsner B. Electromechanical and robot-assisted arm training for improving activities of daily living, arm function, and arm muscle strength after stroke. Cochrane Database of Systematic Reviews. 2018(9).

20. Zhang C, Li-Tsang CW, Au RK. Robotic approaches for the rehabilitation of upper limb recovery after stroke: a systematic review and meta-analysis. International Journal of Rehabilitation Research. 2017 Mar 1;40(1):19-28.

21. Veerbeek JM, Langbroek-Amersfoort AC, Van Wegen EEH, Meskers CGM, Kwakkel G. Effects of robot-assisted therapy for the upper limb after stroke: a systematic review and meta-analysis. Neurorehabil Neural Repair 2016; 1-15.

22. Moher D, Liberati A, Tetzlaff J, Altman DG. Preferred reporting items for systematic reviews and meta-analyses: the PRISMA statement. Annals of internal medicine. 2009 Aug 18;151(4):264-9.

23. Higgins JP, Altman DG, Gøtzsche PC, Jüni P, Moher D, Oxman AD, Savović J, Schulz KF, Weeks L, Sterne JA. The Cochrane Collaboration's tool for assessing risk of bias in randomised trials. Bmj. 2011 Oct 18;343:d5928.

24. Pu L, Moyle W, Jones C, Todorovic M. The effect of a social robot intervention on sleep and motor activity of people living with dementia and chronic pain: A pilot randomized controlled trial. Maturitas. 2021 Feb;144:16-22.

25. Pu L, Moyle W, Jones C, Todorovic M. The effect of using PARO for people living with dementia and chronic pain: A pilot randomized controlled trial. Journal of the American Medical Directors Association. 2020 Aug 1;21(8):107985.

26. Yanagisawa T, Fukuma R, Seymour B, Tanaka M, Hosomi K, Yamashita O, Kishima H, Kamitani Y, Saitoh Y. BCl training to move a virtual hand reduces phantom limb pain: A randomized crossover trial. Neurology. $2020 \mathrm{Jul}$ 28;95(4):e417-26.

27. $\mathrm{Pu}$ L, Moyle W, Jones C. How people with dementia perceive a therapeutic robot called PARO in relation to their pain and mood: A qualitative study. Journal of clinical nursing. 2020 Feb;29(3-4):437-46.

28. Kim MS, Kim SH, Noh SE, Bang HJ, Lee KM. Robotic-assisted shoulder rehabilitation therapy effectively improved Poststroke hemiplegic shoulder pain: a randomized controlled trial. Archives of physical medicine and rehabilitation. 2019 Jun 1;100(6):1015-22.

29. Villafañe JH, Taveggia G, Galeri S, Bissolotti L, Mullè C, Imperio G, Valdes K, Borboni A, Negrini S. Efficacy of short-term robot-assisted rehabilitation in patients with hand paralysis after stroke: a randomized clinical trial. Hand. 2018 Jan;13(1):95-102.

30. Taveggia G, Borboni A, Salvi L, Mulé C, Fogliaresi S, Villafañe JH, Casale R. Efficacy of robot-assisted rehabilitation for the functional recovery of the upper limb in post-stroke patients: a randomized controlled study. Eu- 
ropean journal of physical and rehabilitation medicine. 2016 Jul 13;52(6):767-73.

31. Labruyère R, van Hedel HJ. Strength training versus robot-assisted gait training after incomplete spinal cord injury: a randomized pilot study in patients depending on walking assistance. Journal of neuroengineering and rehabilitation. $2014 \mathrm{Dec} ; 11(1): 1-2$.

32. Paolucci T, Agostini F, Mangone M, Bernetti A, Pezzi L, Liotti V, Recubini E, Cantarella C, Bellomo RG, D’Aurizio C, Saggini R. Robotic rehabilitation for end-effector device and botulinum toxin in upper limb rehabilitation in chronic post-stroke patients: an integrated rehabilitative approach. Neurological Sciences. 2021 Apr 7:1-1.

33. Abdullah HA, Tarry C, Lambert C, Barreca S and Allen $B O$. Results of clinicians using a therapeutic robotic system in an inpatient stroke rehabilitation unit. J Neuroeng Rehabil 2011; 8: 50.

34. Bertani R, Melegari C, Maria C, Bramanti A, Bramanti $P$, Calabrò RS. Effects of robot-assisted upper limb rehabilitation in stroke patients: a systematic review with meta-analysis. Neurological Sciences. 2017 Sep 1;38(9):1561-9.

35. Ferreira FM, Chaves ME, Oliveira VC, Van Petten AM, Vimieiro CB. Effectiveness of robot therapy on body function and structure in people with limited upper limb function: A systematic review and meta-analysis. PloS one. 2018 Jul 12;13(7):e0200330.

36. Geva N, Uzefovsky F, Levy-Tzedek S. Touching the social robot PARO reduces pain perception and salivary oxytocin levels. Scientific reports. 2020 Jun 17;10(1):1-5.

37. Aach M, Cruciger O, Sczesny-Kaiser M, Höffken O, Meindl RC, Tegenthoff M, Schwenkreis P, Sankai Y, Schildhauer TA. Voluntary driven exoskeleton as a new tool for rehabilitation in chronic spinal cord injury: a pilot study. The Spine Journal. 2014 Dec 1;14(12):2847-53.

38. Cruciger O, Schildhauer TA, Meindl RC, Tegenthoff M, Schwenkreis P, Citak M, Aach M. Impact of locomotion training with a neurologic controlled hybrid assistive limb
(HAL) exoskeleton on neuropathic pain and health related quality of life (HRQoL) in chronic SCl: a case study. Disability and Rehabilitation: Assistive Technology. 2016 Aug 17;11(6):529-34.

39. Stampacchia G, Rustici A, Bigazzi S, Gerini A, Tombini T, Mazzoleni S. Walking with a powered robotic exoskeleton: Subjective experience, spasticity and pain in spinal cord injured persons. NeuroRehabilitation. 2016 Jan 1;39(2):277-83.

40. Remy-Neris O, Medee B, Bensmail D, Daveluy W, Benaim C, Froger J, Bonan I, Marque P, Luaute J, Ferrapie $A L$, Yelnik A. Rehabilitation robotics of the upper limb after stroke. The REM_AVC trial. Annals of Physical and Rehabilitation Medicine. $2018 \mathrm{Jul}$ 1;61:e21.

CONFLICT OF INTEREST: Authors declare no conflict of interest

GRANT SUPPORT AND FINANCIAL DISCLOSURE: NIL

\section{AUTHOR'S CONTRIBUTION}

Following authors have made substantial contributions to the manuscript as under

Anjum O: Idea and conceptualization, manuscript writing, final critical review and appraisal

Shaikh HA: Planning, manuscript writing, formatting and critical review

Waheed N: Manuscript writing and critical review

Zaidi SWR: Data searching, manuscript writing and critical review

Authors agree to be accountable for all aspects of the work in ensuring that questions related to the accuracy or integrity of any part of the work are appropriately investigated and resolved. 